\title{
Magmatic and metamorphic evolution of tourmaline-rich rocks of the Sopron area, Eastern Alps (W-Hungary)
}

\author{
Tamás SPRÁNITZ1*, Sándor JÓZSA1', Zoltán KOVÁCS', Benjámin VÁCZI', Kálmán TÖRÖK² \\ ${ }^{1}$ Department of Petrology and Geochemistry, Eötvös Loránd University, Budapest, 1117 Pázmány Péter sétány 1/C, Hungary; \\ spratom.elte@gmail.com \\ ${ }^{2}$ Geological and Geophysical Institute of Hungary, Budapest, 1145 Columbus Str. 17-23, Hungary \\ * Corresponding author
}

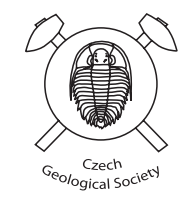

Tourmaline-rich pegmatitic orthogneisses, tourmalinites, kyanite-chlorite-muscovite schists and quartzites crosscut by subordinate quartz-tourmaline veins and layers were newly described from the Sopron area, Western Hungary.

The orthogneisses mainly consist of quartz, plagioclase, tourmaline, garnet and white mica. In smaller amounts K-feldspar, beryl, Mg-rich chlorite, kyanite, lazulite, florencite, monazite and apatite also are present. Magmatic cores and two generations of metamorphic tourmaline (Fe-rich and Mg-rich) were distinguished.

Tourmaline in tourmalinites is generally large (several $\mathrm{cm}$ ), deformed, contains chlorite inclusions and shows oscillatory zoning or polygonal fabric. Large tourmaline crystals often contain dark brown mica-shaped relic areas with higher amount of Ti and Fe than the adjacent parts, interpreted as relics of micas from the protolith. Besides tourmaline, quartz, white mica, plagioclase, apatite, garnet, rutile, ilmenite, scheelite, zircon and monazite are also present in the tourmalinites. Deformed tourmaline-quartz bands and veins occur in kyanite-chlorite-muscovite schists and quartzites. Euhedral, zoned and deformed schorl-dravite is accompanied with kyanite, Mg-chlorite (leuchtenbergite), rutile muscovite and sillimanite. Narrow colorless tourmaline rims enriched exclusively in $\mathrm{Mg}(\mathrm{FeO}<1 \mathrm{wt} . \%)$ can be identified.

Coarse-grained orthogneisses with a significant amount of primary tourmaline-beryl assemblage indicates a fluid-rich, B-Be-bearing environment during the final crystallization of the Variscan peraluminous leucogranite. The formation of tourmalinites can be explained by the related boron metasomatism. Phengitic white mica rims and calcic garnet rims in orthogneisses and tourmalinites indicate high-pressure Alpine metamorphic overprint. The presence of REE-rich phosphate mineralisation and leuchtenbergite in the orthogneisses imply that high salinity fluids metasomatized the orthogneisses along the pre-existing shear zones after the Alpine metamorphic peak. Tourmaline grains in kyanite-bearing quartzites and schists may have originated from a micaschist that underwent a strong Mg-metasomatism during the formation of leucophyllites described from the area.

Keywords: tourmaline, petrography, orthogneiss, tourmalinite, Sopron area, Eastern Alps

Received: 1 November, 2017; accepted: 6 June, 2018; handling editor: M. Novák

\section{Introduction}

The Sopron area is situated at the western margin of the Pannonian Basin and tectonically belongs to the Grobgneiss Series of the Lower Austroalpine nappe system of the Eastern Alps (Török 1996). The metamorphic complex is built up by orthogneisses, micaschists, leucophyllites, quartzites and amphibolites (Fig. 1). Even though the Sopron area is relatively large $\left(\sim 40 \mathrm{~km}^{2}\right)$, the quality and number of outcrops are very poor, and the bedrock lithologies can only be investigated in several old quarries. However, small natural exposures such as outcrops in valleys and autochtonous debris
Tab. 1 Sampled localities; numbers refer to points on the map (Fig. 1)

\begin{tabular}{clll}
\hline No. & \multicolumn{1}{c}{ Locality } & \multicolumn{1}{c}{ GPS } & \multicolumn{1}{c}{ Lithology } \\
\hline 1 & Bükkfaforrás Ditch & $47.641694,16.523134$ & Tourmaline-rich orthogneiss \\
2 & Tövissüveg Hill & $47.641764,16.543157$ & Tourmaline-rich orthogneiss \\
3 & Ultra - NW Foothill & $47.673835,16.517776$ & Tourmalinite \\
4 & Nagy Füzes & $47.651265,16.544219$ & Tourmaline-rich kyanite-muscovite-chlorite schist \\
5 & Seprökötő Hill & $47.656438,16.519159$ & Kyanite-chlorite-muscovite quartzite with tourmaline veins \\
6 & Récényi Road Quarry & $47.655579,16.536048$ & Kyanite-chlorite-muscovite quartzite with tourmaline veins \\
\hline
\end{tabular}

of bedrock show diverse rock types. These include tourmaline-rich rocks, such as tourmaline-rich pegmatitic orthogneisses, tourmalinites, kyanite-chlorite-muscovite schists and quartzites, crosscut by subordinate quartztourmaline veins and bands (0.5-10 cm thick) (Tab. 1).

As tourmaline structure allows a great chemical variation and P-T stability in the Earth's crust, it appears in a wide range of geological environments (e.g. Henry and Dutrow 1996). Consequently, tourmaline can be used to reconstruct the magmatic, metamorphic

\footnotetext{
tochtonous debris
} 


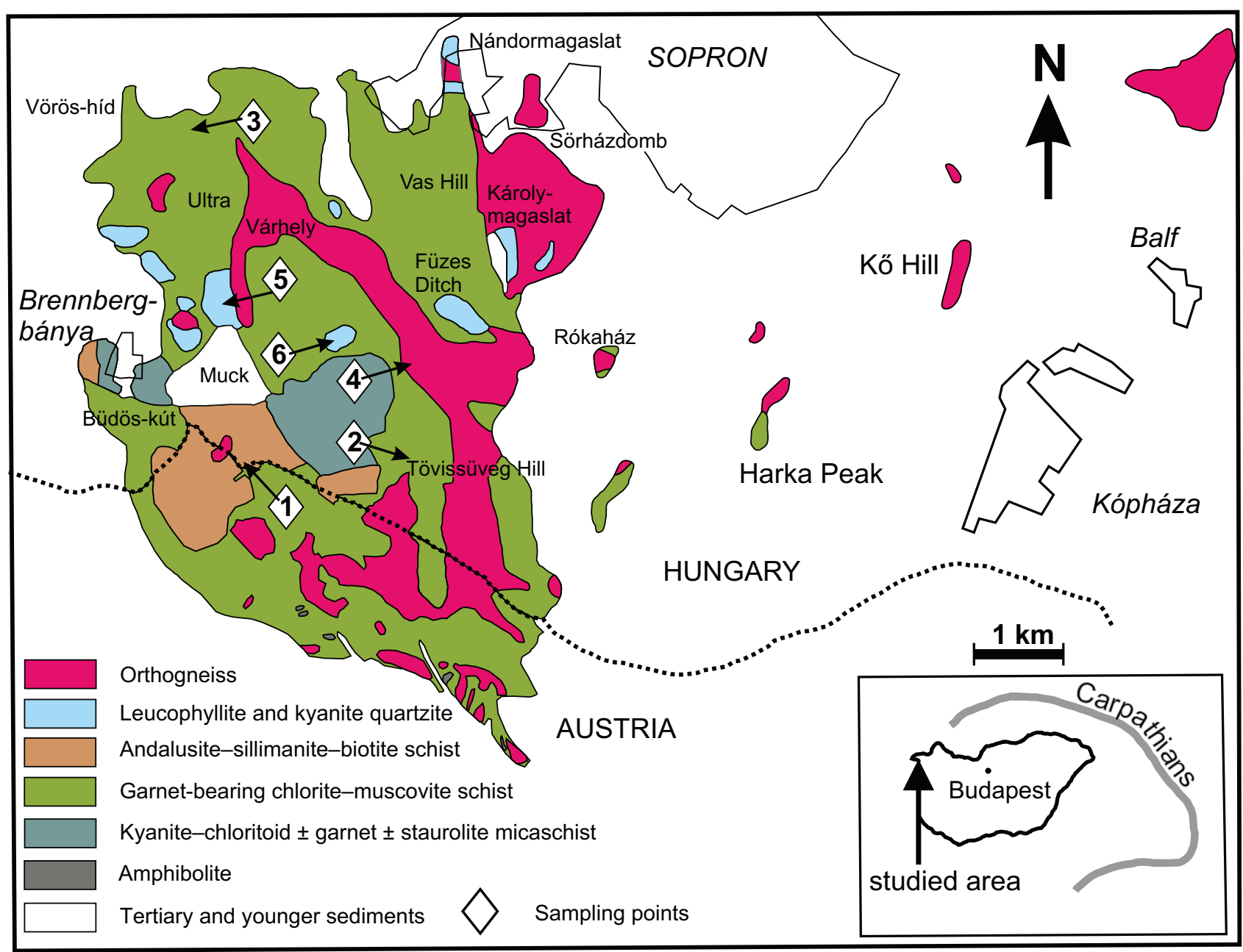

Fig. 1 Schematic geological map of the Sopron Hills (NW Hungary) after Fülöp (1990) and Török (2003); sampling points are indicated (for details, see Tab. 1).

and metasomatic evolution of tourmaline-bearing rock series.

Since the main-element chemistry of tourmaline depends mostly on the geochemical composition of the host rock and $\mathrm{P}-\mathrm{T}$ conditions, characterizing different generations of tourmaline allows to reconstruct the geodynamic processes that affected the Sopron area. The aim of this study is to provide the first detailed description of the tourmaline-rich rocks in the Sopron area and correlate them with the previously observed assemblages using petrographic and major-element geochemical methods.

\section{Geological setting and evolution of the Sopron area}

The Sopron area is built up mostly by medium- and highgrade orthogneisses and micaschists, prevailing over amphibolites, quartzites and leucophyllites (Lelkes-Felvári and Sassi 1983; Kisházi and Ivancsics 1987a; Török 1996). The orthogneisses and micaschists that belong to the Grobgneiss Series of the Wechsel nappe (Lower Austroalpine nappe system) are results of a complex magmatic-metamorphic evolution (Kisházi and Ivancsics 1987a; Janák et al. 2001). The protolith of the orthogneiss was a Variscan peraluminous two-mica leucogranite (Török 1998) that intruded micaschists in the Late Paleozoic. The protolith of micaschists were pelitic-psammitic sedimentary rocks that underwent Caledonian Barroviantype metamorphism (Lelkes-Felvári et al. 1984).

Based on the mineral assemblages of the micaschists, Variscan, Permo-Triassic and Alpine metamorphic imprints can be distinguished, with ages of 329-320 Ma ( $\mathrm{K}-\mathrm{Ar}$ in biotite), 272-236 Ma (K-Ar in biotites) and, 76-71 $\mathrm{Ma}$ ( $\mathrm{Ar}-\mathrm{Ar}$ in phengitic white micas), respectively (Balogh and Dunkl 2005). The orthogneisses record an Alpine HP amphibolite-facies metamorphic imprint, with the peak P-T conditions of $\sim 1.3-1.4 \mathrm{GPa}$ and $450-550^{\circ} \mathrm{C}$ (Török 1998). High-pressure and mediumtemperature Alpine metamorphism implies location at an active continental margin (Török 1998). Zircon fissiontrack data of Balogh and Dunkl (2005) indicate a rapid 
exhumation and cooling following the Late Cretaceous metamorphism.

Orthogneisses can be subdivided into two types based on mineral assemblages and presence of foliation (Török 1998). Besides sheared gneisses with well-developed foliation, unfoliated gneisses (termed metagranites by Török 1998) are also present with well-preserved magmatic texture and assemblage. Primary magmatic phases generally cannot be traced well in the sheared orthogneisses. After the Alpine metamorphic peak, Mg-metasomatism led to the formation of leucophyllites and quartzites in the micaschists and orthogneisses in the close vicinity of shear zones (Török 2001). Demény et al. (1997) discussed a possible fluid source for Mg-metasomatism. According to their interpretation, the mafic-ultramafic complex of the Alpine Penninic Unit underlying the Austroalpine nappes was a likely candidate. REE-rich phosphate mineralisation, caused by late high-salinity fluids, post-dated the formation of leucophyllites and a final stage of limonite-clay mineralisation also reflects the Alpine retrogression (Török 2001; Freiler 2016).

\section{Methods}

Textural analyses were done using optical microscope and Back-Scattered Electron (BSE) imaging. We used the AMRAY 1830 scanning electron microscope equipped with EDAX PV9800 energy-dispersive spectrometer at the Department of Petrology and Geochemistry, Eötvös Loránd University, Budapest. The major-element analyses were carried out by a beam current of $1 \mathrm{nA}$ and an acceleration voltage of $20 \mathrm{kV}$. We applied natural mineral standards of the Smithsonian Institute and the Microspec Co. and ZAF correction using Moran Scientific v 2.3. software to evaluate the

Fig. 2 Macroscopic features of characteristic samples from the six locations: a - Tourmaline-rich orthogneiss (Bükkfaforrás Ditch); b - Tourmaline-rich orthogneiss (Tövissüveg Hill); c - Tourmalinite (Ultra - NW Foothill); d - Tourmaline-rich kyanitemuscovite-chlorite schist (Nagy Füzes); e - Kyanite-chlorite-muscovite quartzite with tourmaline veins (Seprőkötő Hill); f - Kyanite-chlorite-muscovite quartzite with tourmaline veins (Récényi Road Quarry).
EDS spectra. Tourmaline compositions were calculated with the Excel spreadsheet of Andy Tindle (Open University, Milton Keynes, UK from http://www.open.ac.uk) normalizing the analyses to 31 anions and assuming stoichiometric B (3 apfu) with 4 apfu OH. Due to the Bewindow of the instrument, the detection of $\mathrm{Na}$ is imprecise.

Raman spectroscopy was used to identify special mineral phases (beryl and lazulite) in two samples. The analyses were performed at the Instruments Centre of the Institute of Geography and Geology, Eötvös Loránd University. We used a HORIBA JobinYvon LabRAM HR edge filter-based, dispersive, high-resolution confocal Raman microspectrometer.

\section{Results}

\subsection{Petrography}

\subsubsection{Orthogneisses}

The assemblage of rock-forming minerals in orthogneisses (Fig. 2a-b) is represented by coarse-grained

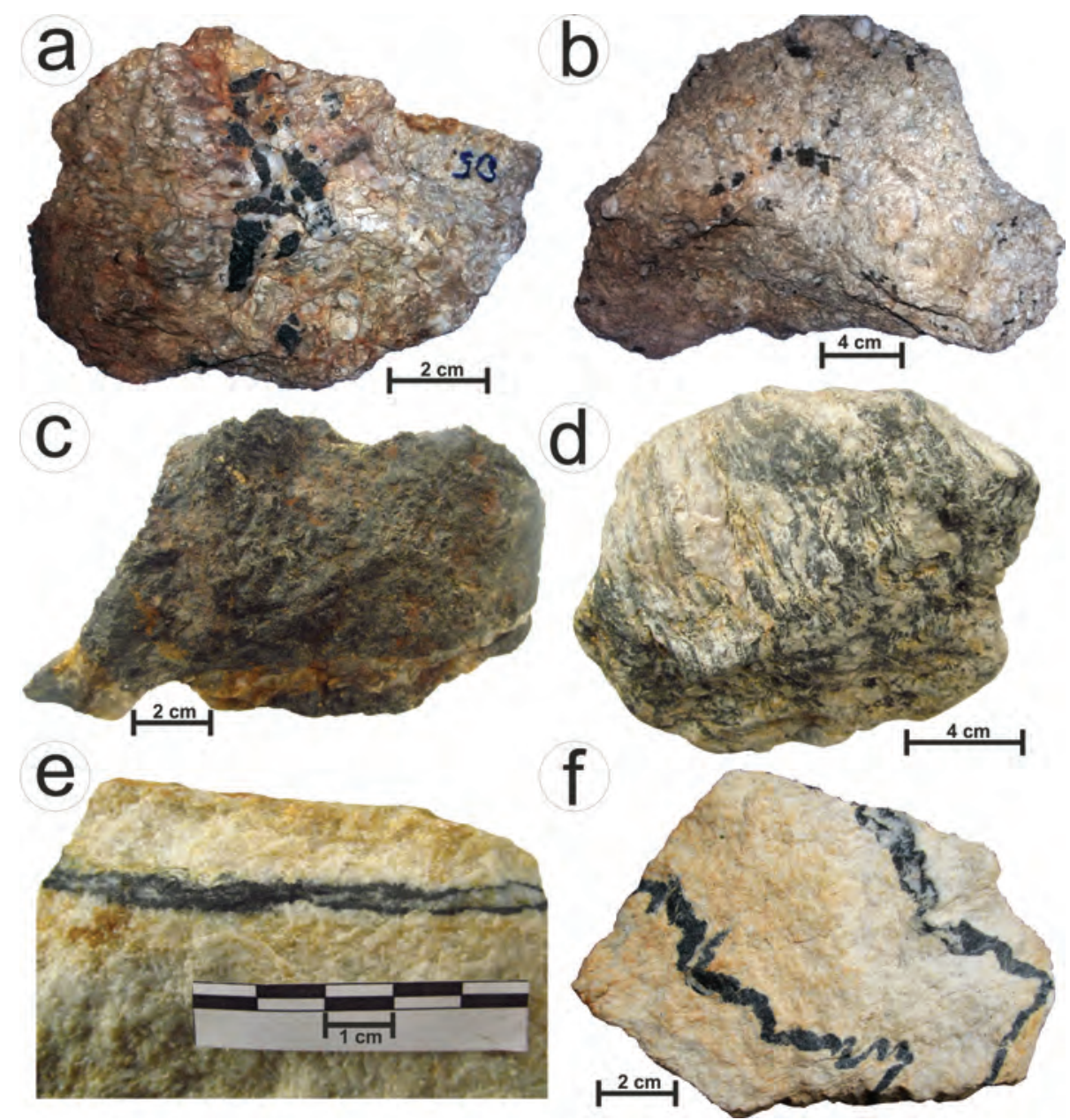



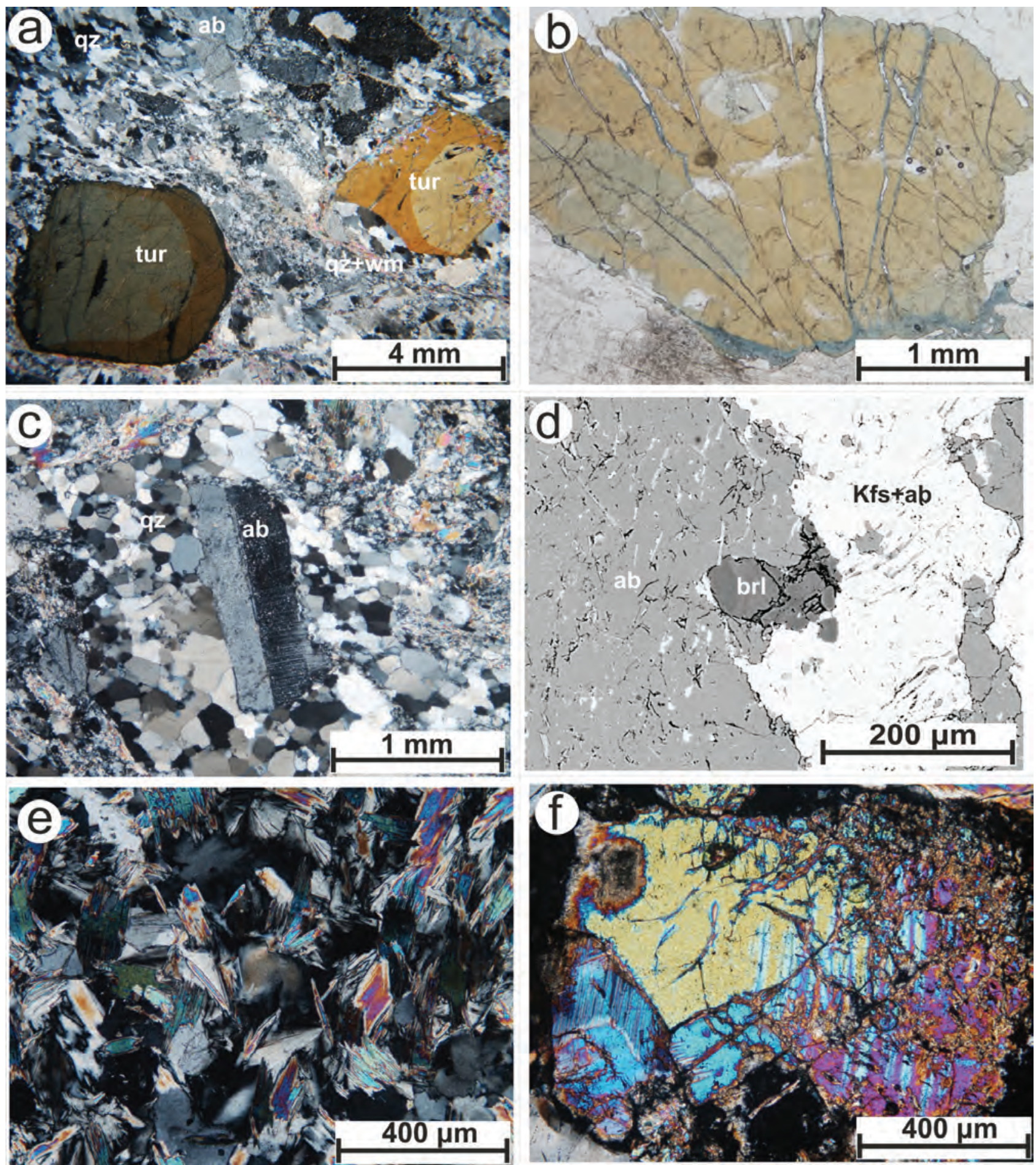

Fig. 3 Typical petrographic features of orthogneisses from Bükkfaforrás Ditch (a-d) and Tövissüveg Hill (e-f). Abbreviations of mineral names are after Whitney and Evans (2010) unless stated otherwise. a - General textural appearance of orthogneisses: euhedral zoned tourmaline (tur) with albite $(\mathrm{ab})$, foliated quartz with fine grained white mica veins (qz + wm) XPL; b - Euhedral, cracked tourmaline with color zoning from an orthogneiss, in cracks white mica appears with brown tourmaline (PPL); c - Euhedral albite with quartz (XPL); d - Beryl, albite and K-feldspar with perthitic lamellae (Kfs $+\mathrm{ab}$ ) in orthogneiss (BSE); $\mathbf{e}-$ Fine-grained quartz, Mg-chlorite and white mica assemblage as a pseudomorph formed after feldspar (XPL); $\mathbf{f}$ - Large lazulite grain in an orthogneiss (XPL).

(up to 1-2 cm) quartz, plagioclase, K-feldspar, tourmaline, garnet and white mica (Fig. 3a). The orthogneisses show variably strong foliation; however, some unfoliated samples (called metagranites by Török 1998) are also present. The foliation is marked by the orientation of quartz. Dynamic recrystallization structure was observed 
in most samples, though quartz in less deformed ones usually shows effects of static recrystallization structure. Plagioclase is present in all samples (Fig. 3c) as a rock-forming mineral, whereas K-feldspar occurs only in unfoliated orthogneisses. Perthitic and antiperthitic exsolution lamellae can often be observed in K-feldspar and albite, respectively (Fig. 3d). All feldspars enclose numerous small (max. 10-20 $\mu \mathrm{m})$ white mica flakes, forming a systematic network along cleavage planes of the feldspar grains. Fine-grained white mica also occurs as thin $(1 \mu \mathrm{m})$ veins crosscutting the rock-forming minerals, whereby the veins are mostly parallel to the foliation.

Tourmaline is usually euhedral and shows strong color-zoning (pale yellowish-brown, pale brown and light bluish-green from core to rim; Fig. 3b). Even though the boundary is sharp between the lighter cores and the surrounding darker zones, this optical difference cannot be distinguished in the BSE images. Most of the tourmaline grains are fractured and show deformation parallel to the foliation of the rock. Dark brown or greenish-blue rims and light blue or nearly colorless crack-fillings are also frequent. Greenish-blue and dark brown tourmaline replaces inner tourmaline zones and forms overgrowths whereas in cracks it generally occurs with white mica (Fig. 3b). Quartz inclusions are abundant in greenish-blue tourmaline as well.

Some unfoliated, pegmatitic orthogneisses contain ber$\mathrm{yl}$ in small amounts appearing along coarse perthitic Kfeldspar grains (1-2 $\mathrm{mm}$ ) which is the first occurrence of the mineral in the region (Fig. 3d). In some orthogneisses, feldspars are completely replaced by fine-grained white mica, Mg-rich chlorite and quartz (Fig. 3e). Additionally, kyanite and a wide variety of phosphate minerals (lazulite, florencite, goyazite-plumbogummite-crandallite, monazite, xenotime and apatite) are also present (Fig. 3f). Phosphates occur along cracks, interstitially or in feldspar pseudomorphs as fine-grained aggregates. Kaolinization of white mica is detected at contact with lazulite. Finegrained apatite rims the phosphate aggregates. Apatite is fairly frequent as inclusions in feldspar and near white mica-rich fine-grained veins as well.

\subsubsection{Tourmalinites}

Tourmalinites occur as massive black boulders containing up to 80 vol. \% tourmaline and variable amounts of quartz veins and bands (Fig. 2c). Tourmaline generally forms several $\mathrm{cm}$ long, deformed crystals, often with chlorite inclusions (Fig. 4a). Tourmaline shows mosaic pattern with polygonal fabric, as well as color zonation (Fig. 4b-f). The cores of the tourmaline crystals are greenish-blue, passing outwards to greenish-brown zones (frequently with oscillatory zoning close to the rim) followed by dark brown rims. Moreover, bluish-colorless tourmaline occurs as crack fillings (Fig. 4c-d). Darkbrown tourmaline is also present as crack fillings in the fractures of bigger tourmaline grains, often replacing inner zones. The boundary between the greenish-blue core and greenish-brown zones is rather gradual.

Dark brown, mica-shaped patches or relics (Fig. 4b) occur inside tourmaline crystals. Rutile and ilmenite containing fine-grained scheelite inclusions (Fig. 4g) can be observed interstitially and as inclusions in tourmaline as well. Accessory apatite, white mica, albite, garnet, biotite, zircon and monazite are associated with quartz-rich layers. Phosphates (apatite and monazite) also form fine-grained veins or crack-fillings in tourmaline crystals. Brecciated type can be distinguished as a special subfacies of the tourmalinite (Fig. 4h), whereby limonite-hematite forms the matrix and the clasts are mostly tourmaline and quartz.

\subsubsection{Tourmaline-rich kyanite-chlorite- muscovite schists and quartzites}

Kyanite-chlorite-muscovite schists and quartzites are strongly deformed rocks, where the foliation is marked by alternating quartz-, kyanite-, chlorite-, white mica- and rutile-rich domains. Tourmaline-rich bands and veins are usually parallel to the foliation, but locally they crosscut it perpendicularly (Fig. 2d-f). Deformed kyanite grains are irregularly shaped with stepwise grain boundaries. Colorless chlorite (leuchtenbergite, according to classification of Kisházi and Ivancsics 1987b) and white mica form an oriented network of fibers and needles; rutile appears as elongated grains and clusters. Sillimanite needles often occur in the core of white micas as a relic phase. Occasionally, post-kinematic chloritoid-rich domains push back the white micas.

The euhedral, zoned and deformed crystals of tourmaline, up to $1 \mathrm{~mm}$ in size, always show zoning; light greenish-bluish core, darker brownish outer zones and a narrow, colorless rims can be identified (Fig. 5a-b). Oscillatory zoning was observed in dark brownish outer zones; the core is separated by a sharp boundary. Narrow colorless tourmaline rims overgrow the grains and fill their fractures; their boundary show generally replacing textures (Fig. 5b).

\subsection{Mineral chemistry}

\subsubsection{Garnet}

Chemical data on garnets are summarized in Tab. 2 . Although precise $\mathrm{Fe}^{2+} / \mathrm{Fe}^{3+}$ distribution cannot be calculated from our dataset (due to low accuracy of EDS analyses and the contents of minor oxides such as $\mathrm{V}_{2} \mathrm{O}_{3}$, and $\mathrm{Cr}_{2} \mathrm{O}_{3}$ that are below detection limit), the formula 

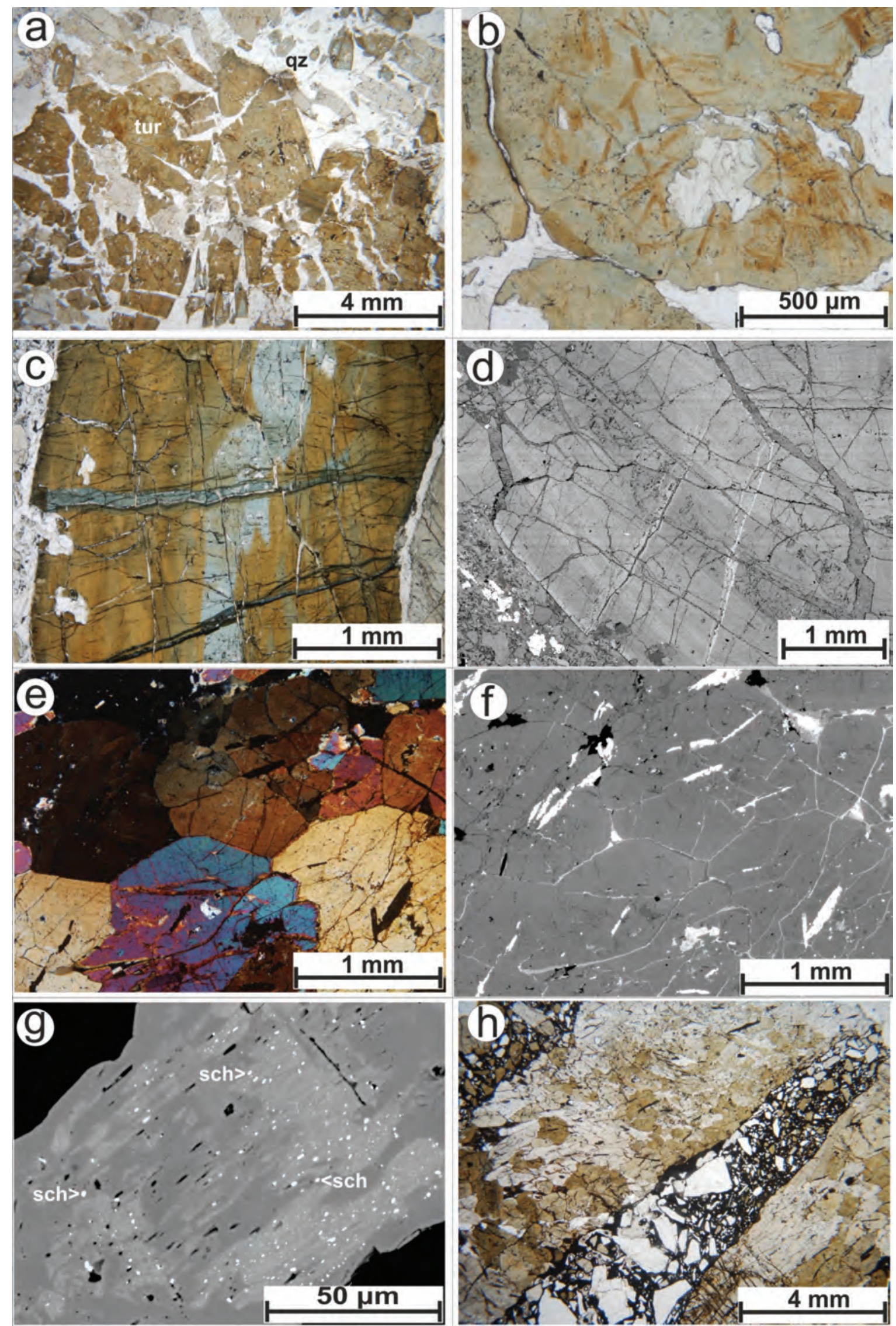
Tab. 2 Representative EDS analyses of garnet from the tourmaline-rich rocks of the Sopron area (wt. \% and apfu)

\begin{tabular}{|c|c|c|c|c|c|c|c|c|c|c|c|c|}
\hline & & & orth & eiss, B & kkfaforrá & tch & & & tourn & nite, $\mathrm{U}$ & $\mathrm{a}-\mathrm{NW}$ & thill \\
\hline & 1 & $\pm 2 \sigma$ & 2 & $\pm 2 \sigma$ & 3 & $\pm 2 \sigma$ & 4 & $\pm 2 \sigma$ & 5 & $\pm 2 \sigma$ & 6 & $\pm 2 \sigma$ \\
\hline $\mathrm{SiO}_{2}$ & 36.32 & 0.39 & 36.70 & 0.39 & 37.23 & 0.39 & 37.08 & 0.39 & 36.94 & 0.40 & 36.86 & 0.46 \\
\hline $\mathrm{Al}_{2} \mathrm{O}_{3}$ & 21.62 & 0.31 & 21.27 & 0.31 & 21.74 & 0.31 & 21.86 & 0.31 & 22.73 & 0.33 & 23.05 & 0.39 \\
\hline $\mathrm{FeO}^{*}$ & 25.62 & 0.31 & 28.05 & 0.33 & 31.19 & 0.36 & 30.08 & 0.35 & 21.49 & 0.30 & 24.53 & 0.38 \\
\hline $\mathrm{MnO}$ & 14.85 & 0.22 & 11.64 & 0.19 & 2.91 & 0.08 & 3.89 & 0.10 & 9.78 & 0.18 & 5.98 & 0.16 \\
\hline MgO & 1.41 & 0.05 & 2.09 & 0.07 & 2.62 & 0.09 & 2.53 & 0.08 & 2.09 & 0.07 & 2.20 & 0.09 \\
\hline Total & 100.00 & 0.63 & 100.00 & 0.63 & 100.00 & 0.63 & 100.00 & 0.63 & 100.00 & 0.64 & 100.00 & 0.75 \\
\hline Si & 2.96 & & 2.98 & & 2.98 & & 2.97 & & 2.94 & & 2.93 & \\
\hline $\mathrm{Al}$ & 2.08 & & 2.04 & & 2.05 & & 2.06 & & 2.13 & & 2.16 & \\
\hline $\mathrm{Fe}$ & 1.75 & & 1.90 & & 2.09 & & 2.01 & & 1.43 & & 1.63 & \\
\hline Mn & 1.03 & & 0.80 & & 0.20 & & 0.26 & & 0.66 & & 0.40 & \\
\hline Mg & 0.17 & & 0.25 & & 0.31 & & 0.30 & & 0.25 & & 0.26 & \\
\hline cat. sum & 8.00 & & 8.00 & & 8.00 & & 8.00 & & 8.00 & & 8.00 & \\
\hline almandine & 59 & & 64 & & 70 & & 68 & & 50 & & 55 & \\
\hline pyrope & 6 & & 8 & & 11 & & 10 & & 8 & & 9 & \\
\hline grossular & 1 & & 1 & & 12 & & 13 & & 20 & & 22 & \\
\hline spessartine & 34 & & 27 & & 7 & & 9 & & 22 & & 14 & \\
\hline
\end{tabular}

Cation numbers are on the basis of $12 \mathrm{O}$

1-2 - cores of garnets (Fe-Mn-rich) from an orthogneiss, 3-4 - rims of garnets (Ca-rich) from an orthogneiss, 5-6 - Ca-rich metamorphic garnet from a tourmalinite

$\mathrm{FeO}^{*}$ - total iron as $\mathrm{FeO}$
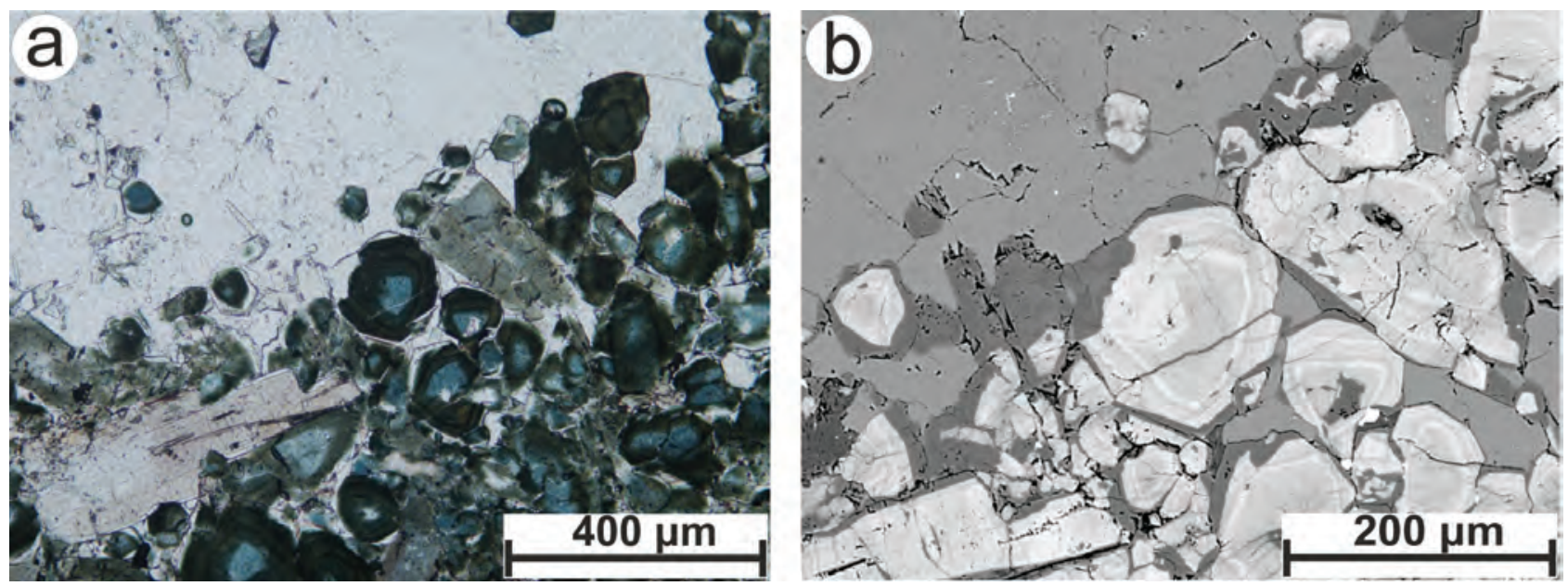

Fig. 5 Tourmaline-rich zone in kyanite-chlorite-muscovite quartzite from the Récényi Road Quarry. a - Photomicrograph of color-zoned tourmaline aggregate with colorless tourmaline rims $(1 \mathrm{~N})$; $\mathbf{b}$ - Detailed BSE image of the previous figure's center, the optically colorless tourmaline forms dark-grey rims.

calculations gave reasonable results. We assume that the octahedral site is occupied by $\mathrm{Al}$ whereas the ratio

Fig. 4 Petrographic features of tourmalinites from Ultra - NW Foothill. Abbreviations of mineral names are after Whitney and Evans (2010) unless stated otherwise. a - Typical texture of tourmalinite: deformed tourmaline- and quartz-rich (upper right) domains (PPL); b - Reddish-brown mica-shaped fabric in a large tourmaline crystal (PPL); c-d - Color zoning of a tourmaline in a tourmalinite (PPL, BSE); e-f - Equigranular and granoblastic texture in tourmaline (XPL and $\mathrm{BSE}$ ); $\mathbf{g}$ - Scheelite inclusions in rutile (BSE); $\mathbf{h}$ - Brecciated subfacies of the tourmalinite (PPL). of the divalent cations at the dodecahedral site shows differences among the investigated rocks. The cores of garnets from orthogneisses are rich in Fe and $\mathrm{Mn}$ and extremely poor in Ca; however, the grains typically have thin $(10-20 \mu \mathrm{m})$ Ca-rich rims (Fig. 6). This zoning is in agreement with magmatic garnet core compositions and Alpine metamorphic garnet core/rim compositions described from garnet-bearing orthogneisses by Török (1998) (Fig. 7). The garnets from tourmalinites resemble Alpine metamorphic garnet rim described by Török (1998). 


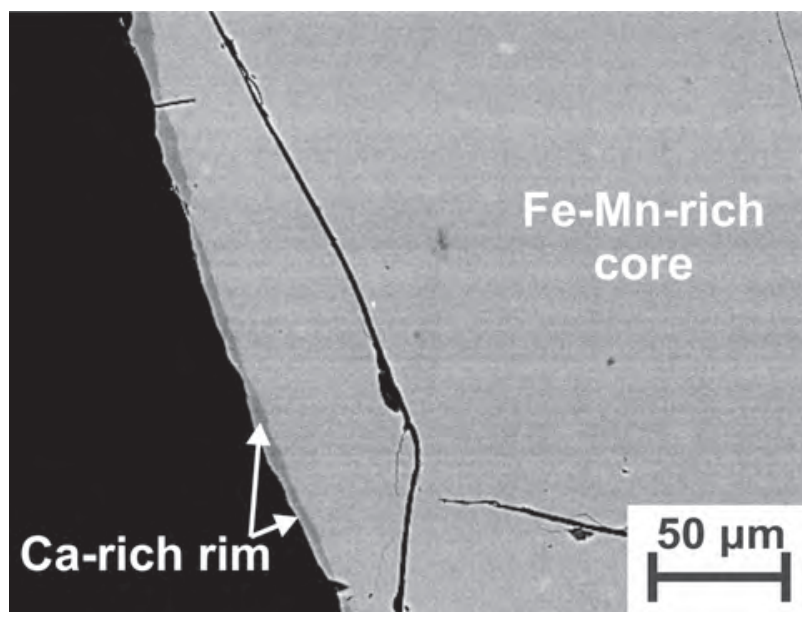

Fig. 6 Back-scattered electron image of a zoned garnet from the orthogneiss of Bükkfaforrás Ditch (for major-element data, see Tab. 2).

\subsubsection{White mica}

White micas in orthogneisses always show a rimward increase in Si contents (Fig. 8); high-Si white mica can be observed along tourmaline fractures as well. Small white mica inclusions in feldspars also show phengitic composition (Si up to $6.55 \mathrm{apfu}$; Tab. 3). Significantly higher Si contents (more than $6.8 \mathrm{apfu}$ ) were found in white micas in tourmalinites, while lower values can be measured in mica inclusions in albite. Generally, white micas with lower $\mathrm{Si}(<6.4 \mathrm{apfu})$ are significantly enriched in $\mathrm{TiO}_{2}$ (> 1.2 wt. \%). White micas from tourmaline-rich kyanitemuscovite-chlorite schists and quartzites are extremely enriched in $\mathrm{Mg}$ (\#Mg > 0.9) (Fig. 9).

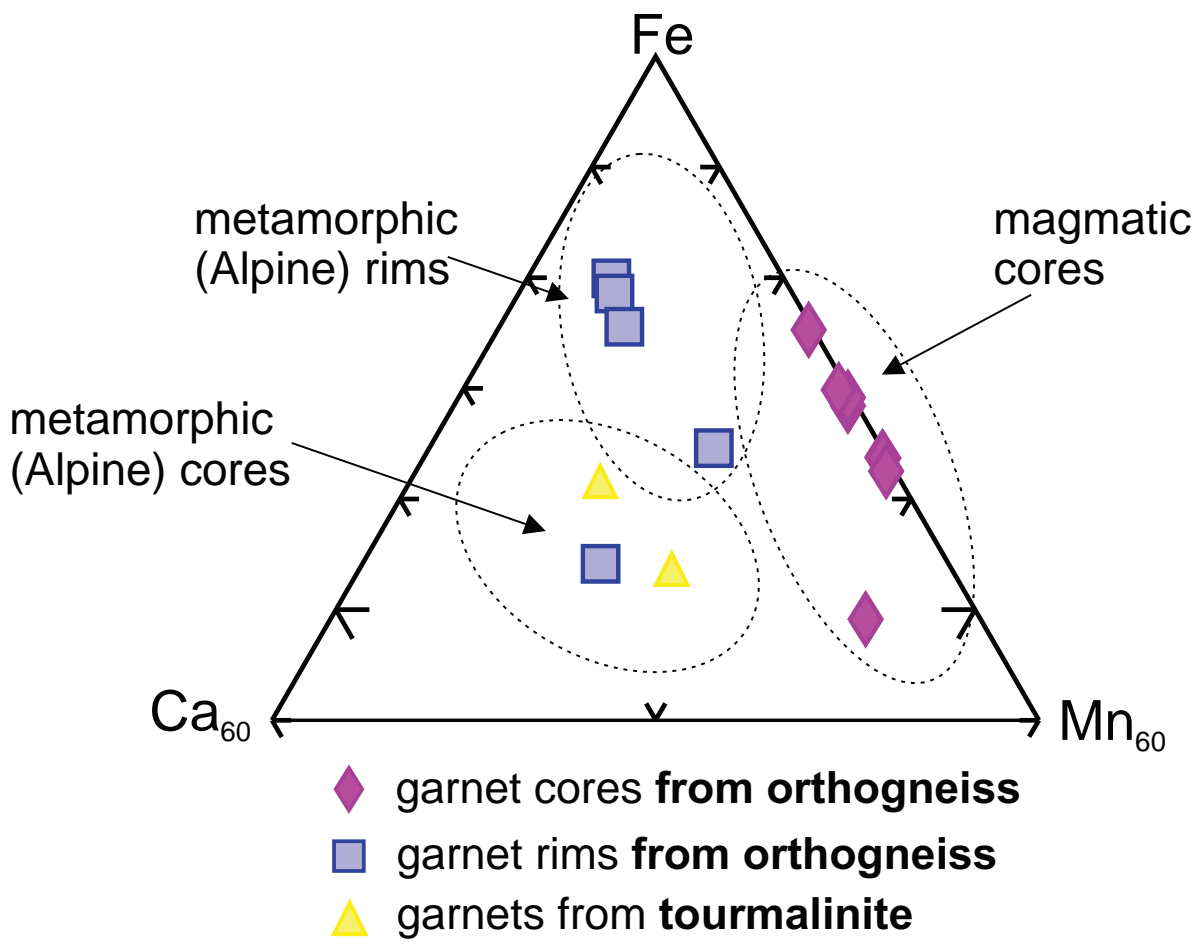

\subsubsection{Tourmaline}

The major-element composition of tourmaline in the studied lithologies shows a wide variation along the schorl-dravite solid-solution line. Aside from variations at the Y-site octahedra ( $\mathrm{Fe}, \mathrm{Mg}$ ), the tourmalines also vary significantly in their $\mathrm{Ca} /(\mathrm{Ca}+\mathrm{Na})$ ratio at the $\mathrm{X}$-site. However, the $\mathrm{CaO}$ content was usually around the detection limit ( 0.5 wt. \%) and analysis of $\mathrm{Na}_{2} \mathrm{O}$ uncertain due to the Be-window of the instrument. Without precise compositional data we were unable to make correct tourmaline formula calculations and therefore we only worked with the cation ratios of the $\mathrm{Y}$ and $\mathrm{Z}$ sites (assuming that the $\mathrm{T}$ site is fully occupied by Si atoms, and all Fe is in the form of FeO; Tab. 4).

The geochemical composition of all tourmaline zones in orthogneisses fits to the schorl-dravite solid solution (Fig. 10). Tourmaline cores show a schorlitic composition, generally fitting in the granitoid field of the diagram by Henry and Guidotti (1985) (Fig. 10). Dark brown or greenish-blue tourmaline rims and crack fillings are enriched in Fe; on the other hand, light blue and nearly colorless crack fillings and rims are Mg-rich.

Tourmaline composition from tourmalinites varies in a wide range: the light blue cores and brownish regions with oscillatory zoning are schorl-dravite solid solutions and dark brown rims and crack-fillings are almost pure schorl. However, in some bluish-colorless cracks nearly pure dravite compositions were observed (Fig. 11). Cores are always richer in $\mathrm{Mg}$, while oscillatory zoning is caused by alternating $\mathrm{Mg} / \mathrm{Fe}$.

Tourmaline in kyanite-muscovite-chlorite schists shows an intermediate schorl-dravite composition, similar to the core and lighter zones of tourmaline in kyanite-muscovite-chlorite quartzites (Fig. 12). Darker brownish outer tourmaline zones of the quartzites proved to be schorl. Additionally, the narrow colorless tourmaline rim is dominated by $\mathrm{Mg}(\mathrm{FeO}<1$ wt. \%) (Tab. 4).

Fig. 7 Distribution of garnet compositions from orthogneisses and tourmalinites in the $\mathrm{Ca}_{60}-\mathrm{Fe}-\mathrm{Mn}_{60}$ ternary diagram. Dashed areas: data of Török (2003) from orthogneisses of the Sopron area. 


\section{Discussion}

\subsection{Tourmaline-rich orthogneisses}

\subsubsection{Magmatic assemblage}

Perthitic K-feldspars and antiperthitic albites can be identified as relict magmatic phases in unfoliated orthogneisses (Fig. 3d). The chemical composition of plagioclase is almost exclusively pure albite; K-feldspar $\left(\mathrm{Or}_{100} \mathrm{Ab}_{0}\right)$ is only present in the unfoliated orthogneisses. Muscovitic (low $\mathrm{Si}$ ) white mica cores are interpreted as primary magmatic relicts as are the $\mathrm{Fe}-\mathrm{Mn}$-rich cores of the zoned garnet (Török 1998).

Beryl and the cores of tourmaline can also be seen as magmatic (pegmatitic) phases, although not all tourmaline core compositions fall into the field of granitoid rocks on the diagram of Henry and Guidotti (1985) (Fig. 10). Even though schorl is the characteristic representative of tourmaline in felsic plutonic rocks (Slack 1982), there are also examples of granitic-pegmatitic systems where tourmaline is rich in $\mathrm{Mg}$ (e.g. Balen and Petrinec 2011; Zahid et al. 2013). Major- and trace-element chemistry (e.g. $\mathrm{Mg} / \mathrm{Fe}$ ) of tourmaline in pegmatitic bodies can be greatly influenced by the composition of the host rock (Ertl et al. 2010). Similarly, based on Zahid et al. (2013), there are three possible explanations for such Mg-rich tourmaline composition in a felsic plutonic system: (1) tourmaline originated from the host metamorphic or sedimentary rock, (2) tourmaline formed during interaction between the host rock and the intruding magma, or, (3) the geochemical signature of the pelitic source region of the melt is preserved and tourmaline crystallized as a magmatic phase.

\subsubsection{Metamorphic assemblage}

Secondary white micas forming crack-fillings in feldspars, tourmalines and overgrowths of magmatic muscovites, show a phengitic (high Si) composition (Tab. 3), that is an important indicator of the Alpine high-pressure metamorphism, as are narrow Ca-rich overgrowths of Fe-Mn garnets (Fig. 7) (Török 1996, 1998). Such Ca-rich garnet overgrowth indicating Alpine metamorphism was also recorded in metagranitoids in the Veporic Unit (Plašienka et al. 1999).

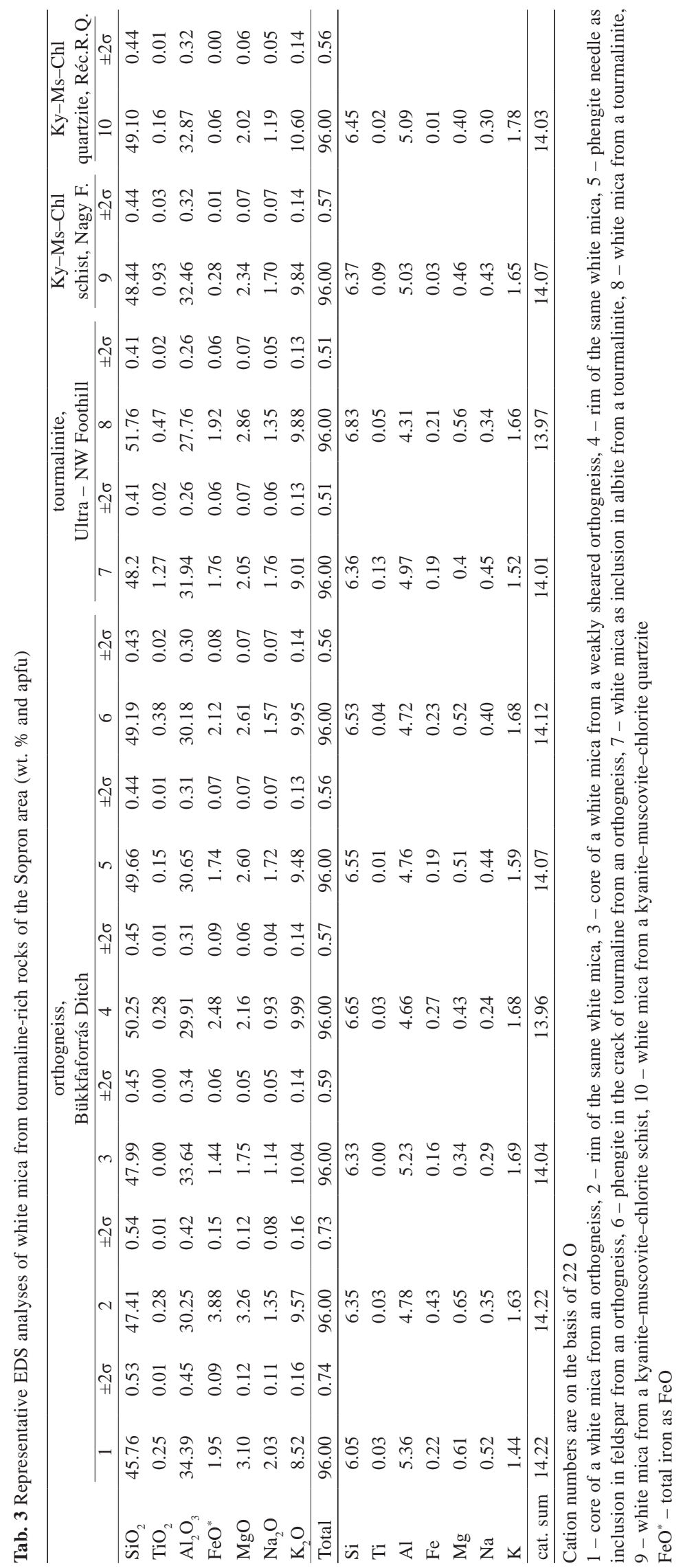




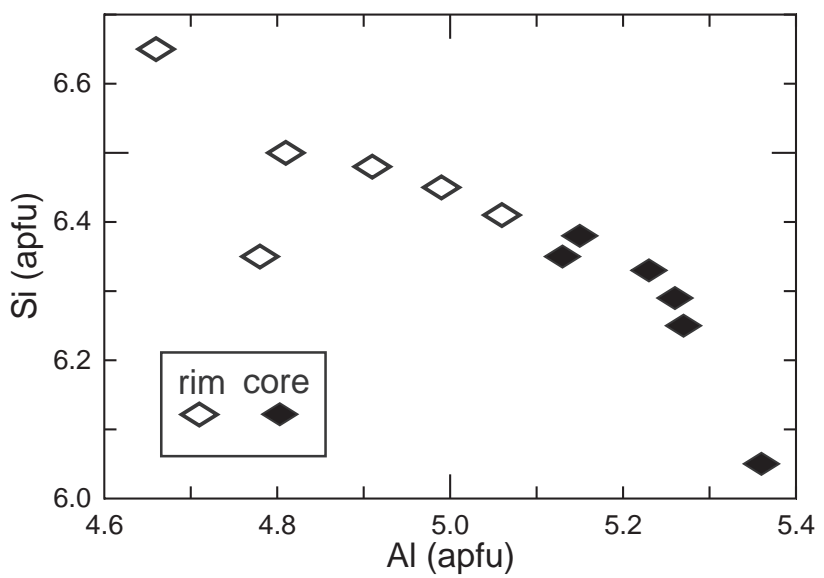

Fig. 8 Si vs. Al (apfu) diagram for white micas from orthogneisses: muscovitic cores with lower, and phengitic rims with higher Si contents.

In some orthogneisses, feldspars are completely replaced by a fine-grained assemblage of quartz, muscovite and Mg-chlorite (Fig. 3d). The origin of the Mg-chlorite (leuchtenbergite) may be related to the Mg-metasomatism, which took place after the peak of the Alpine HP metamorphism and caused the formation of leucophyllites along the shear zones in the Sopron area (Török 2001, 2003).

Textural data confirm that kyanite is the member of the Alpine HP assemblage; therefore the record of the Mg-metasomatic event can be traced not only in the leucophyllites but also in the orthogneisses. The presence of phosphate mineralisation confirms the close vicinity of the altered orthogneisses to the shear zones, as the same mineral assemblage was recorded by Török
(2001) in leucophyllites. Textural and geochemical analyses show the following typical sequence of the different phosphates: (1) Mg-rich lazulite and Ce-rich florencite, (2) Sr-bearing goyazite, Ca-bearing crandallite and Pb-bearing plumbogummite, (3) apatite rims. This series reflects the change in composition of the latest high-salinity fluids attributed to the retrograde stage of Alpine metamorphism (Török 2001). Uher et al. (2009) described lazulite and Ba, Sr, Ca and K-rich phosphates-sulphates in metaquartzites from Tríbeč Mountains, Western Carpathians. The authors suggested the underlying Hercynian granitic rocks as the most likely source of the fluids that caused phosphate mineralisation in the metamorphic sequence.

Based on textural evidence, two different types of metamorphic tourmaline occur as overgrowths and/ or crack-fillings: the Fe-rich brownish-greenish zones, and the Mg-rich light bluish or nearly colorless zones (Fig. 10). The latter tourmaline generation can be linked to the formation of the Mg-rich mineral assemblage occurring in orthogneisses (Mg-rich chlorite, Mg-rich muscovite) that was formed during the Mg-metasomatism of the area (Török 2001).

\subsection{Tourmalinites}

\subsubsection{Primary assemblage(?)}

Large tourmaline crystals in tourmalinites contain mica-shaped areas (Fig. 4d) with higher amounts of $\mathrm{Ti}$ and Fe compared to the neighboring parts (Tab.

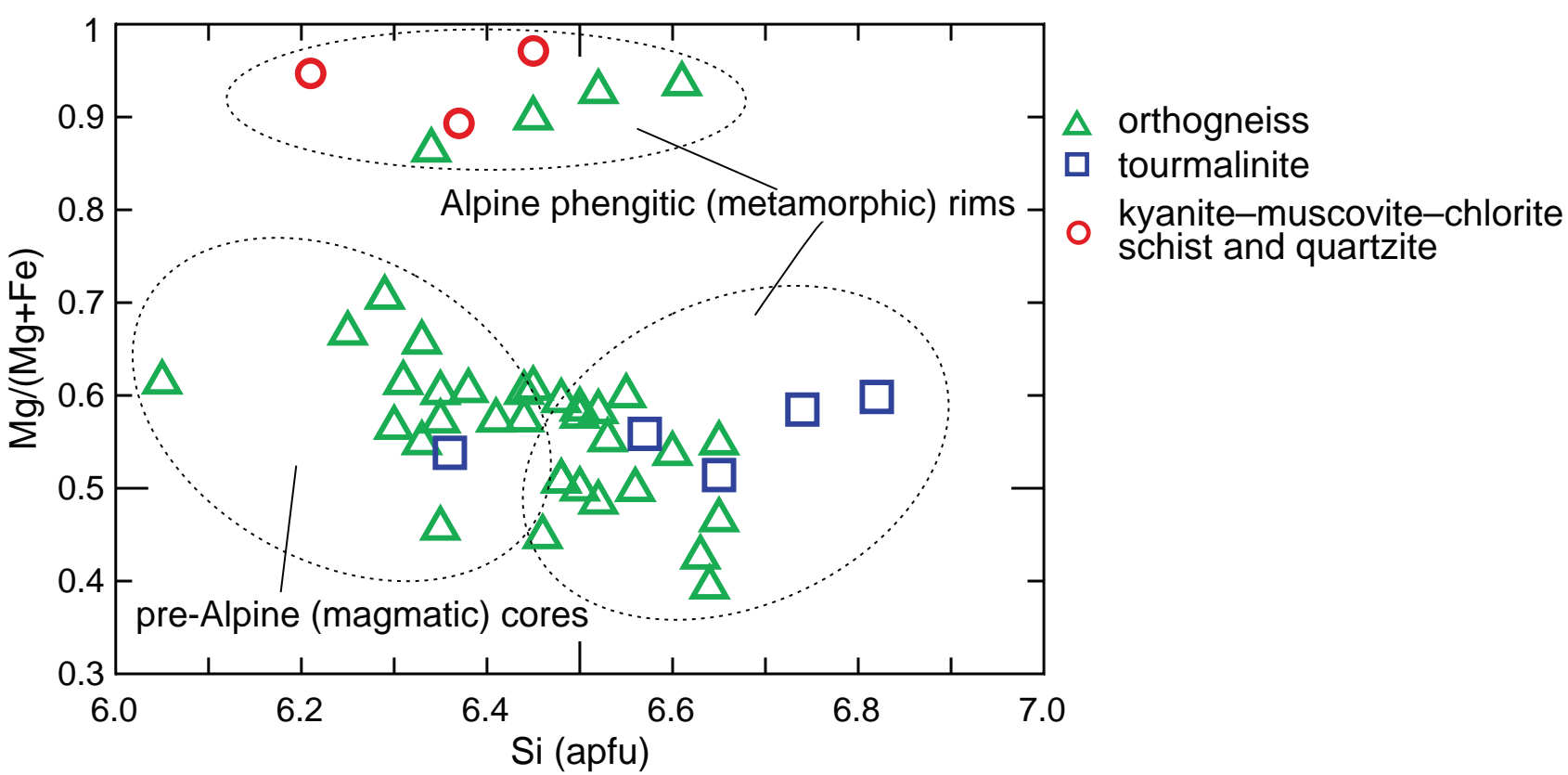

Fig. 9 White mica compositions from orthogneisses, tourmalinites and tourmaline-rich kyanite-muscovite-chlorite schists and quartzites in the $\mathrm{Mg} /(\mathrm{Mg}+\mathrm{Fe})$ vs. Si (apfu) discrimination diagram. Dashed fields are based on Török (2001). 
4). During the process of tourmalinization, rock-forming minerals of the host rock (e.g. feldspar and mica) are commonly replaced by tourmaline (Henry and Dutrow 1996; London et al. 1996). Therefore such fabric can be interpreted as relic micas from the protolith. Fine-grained scheelite inclusions in rutile (Fig. 4g) can also be interpreted as relics, since scheelite could break down during metamorphic reactions (Plimer 1987; Cave et al. 2015). However, the presence of scheelite may confirm that tourmalinites developed by contact metasomatic processes near granitoid intrusions, and such lithologies are significant indicators of $\mathrm{Sn}-\mathrm{W}$ greisen ore deposits (e.g. Raith 1988; Slack 1996; Henry and Brodtkorb 2009; Marks et al. 2013). Low-Si, high-Ti white mica inclusions in albite can also be interpreted as a pre-Alpine relict phase.

\subsubsection{Metamorphic assemblage}

All of the white micas that do not occur as inclusions in feldspar have phengitic compositions ( $\mathrm{Si}$ $>6.82$ apfu; Tab. 3), indicating Alpine HP metamorphism (Török 1996). Garnets of the tourmalinites are Ca-rich, which implies Alpine metamorphic origin, similarly to the Ca-rich garnet rims in orthogneisses (Fig. 7). As tourmaline crystals are usually strongly deformed, tourmalinites may record a metamorphic overprint. Furthermore, equigranular and granoblastic texture (polygonal fabric with triple grain junctions of $c .120^{\circ}$, Fig. 4c) confirms the effect of HP (amphibolite-facies) metamorphic recrystallization (Slack 1996). The Fe-rich tourmaline generation that forms the dark brown rims are overgrow the cores, but pre-dated the light blue to nearly colorless Mg-rich crack-fillings (Fig. 11).

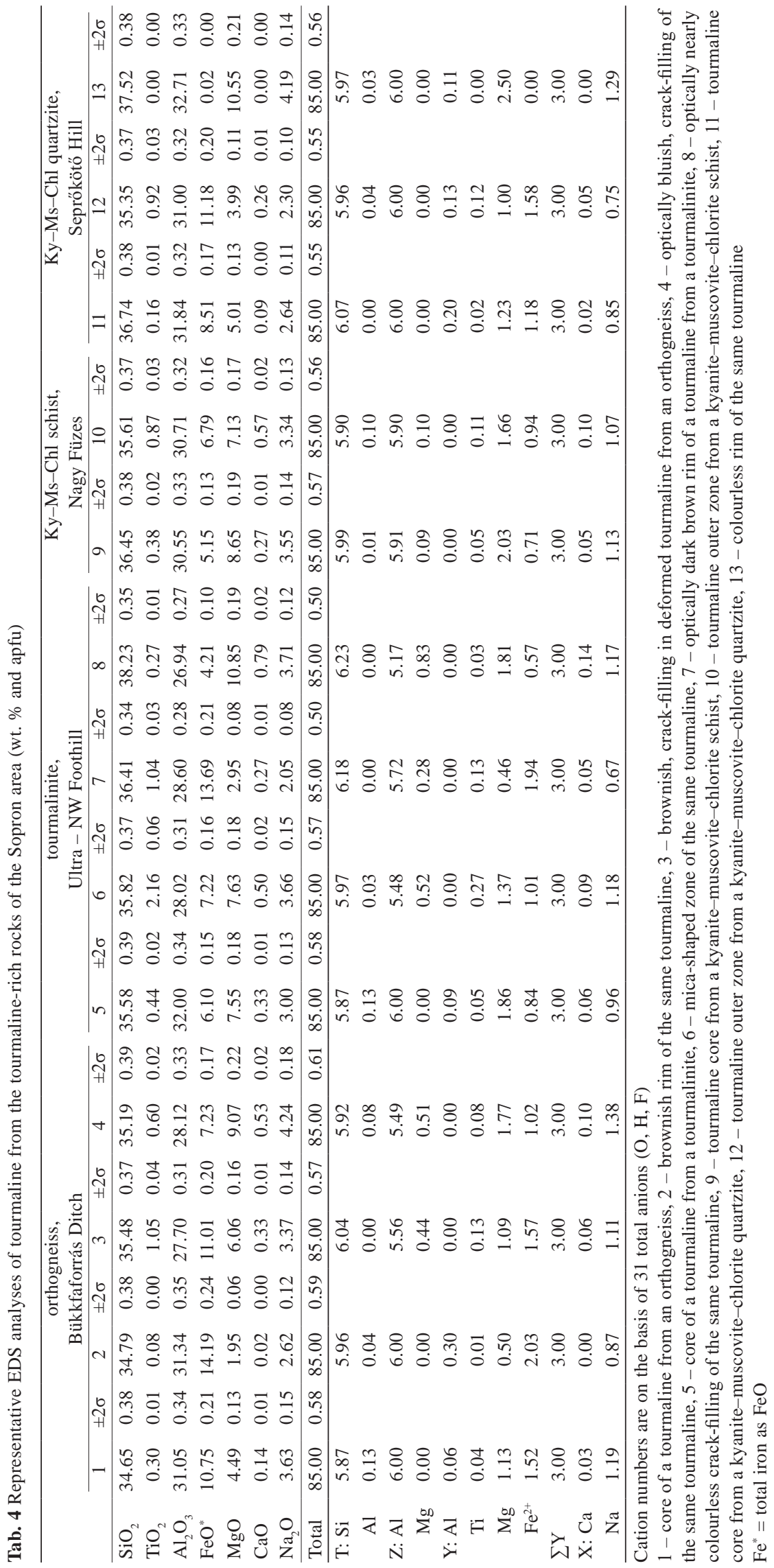




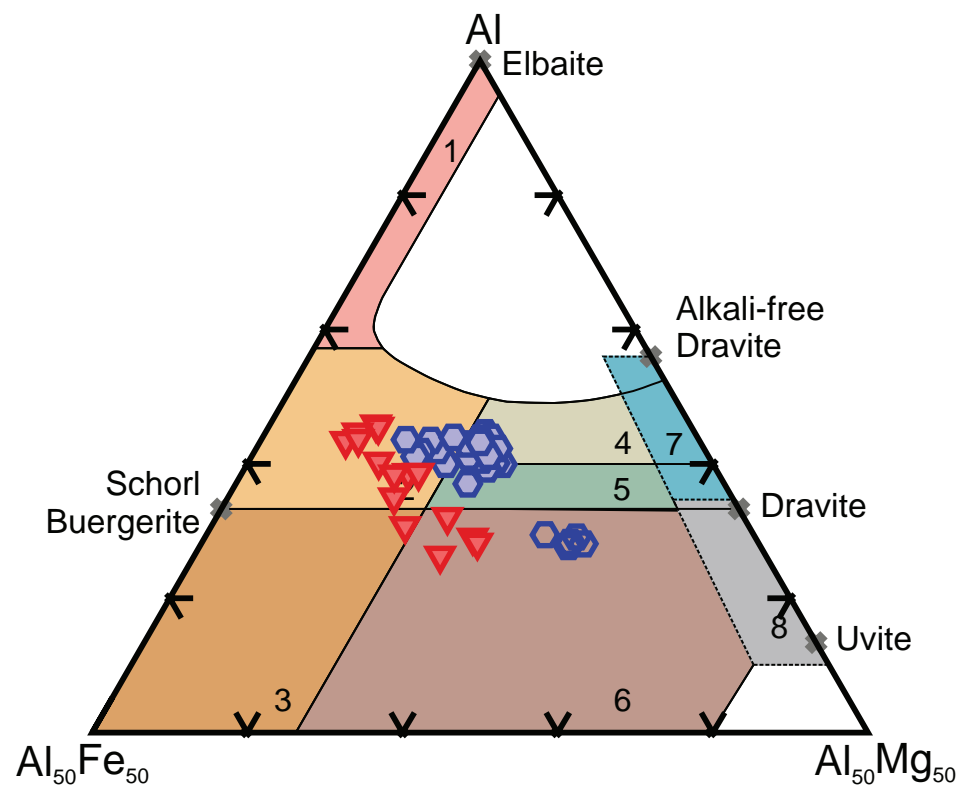

1 Li-rich granitoid pegmatites and aplites

2 Li-rich granitoids and their associated pegmatites and aplites

$3 \mathrm{Fe}^{3+}$-rich quartz-tourmaline rocks

4 Metapelites and metapsammites coexisting with an Al-saturated phase
Metapelites and metapsammites not coexisting with an Al-saturated phase

$6 \mathrm{Fe}^{3+}$-rich quartz-tourmaline rocks, calc-silicate rocks and metapelites

7 Low-Ca metaultramafics and $\mathrm{Cr}$, V-rich metasediments

8 Metacarbonates and meta-pyroxenites

\section{Orthogneisses \\ - core \\ $\nabla$ dark brown or greenish-blue rim and crack-filling \\ - colourless or light blue rim and crack-filling}

Fig. 10 Distribution of tourmaline compositions from the orthogneisses in the $\mathrm{Al}_{50} \mathrm{Fe}_{50}-\mathrm{Al}-\mathrm{Al}_{50} \mathrm{Mg}_{50}$ triangle. Compositional areas are based on Henry and Guidotti (1985).
The Fe-rich tourmaline could probably be formed during prograde metamorphism (Henry and Dutrow 1996), whereas the Mg-rich tourmaline generation (together with the Mg-rich chlorite) seems an indicator of the Alpine retrograde Mg-metasomatic event. Late stage apatite-monazite veins and crack-fillings may record the effect of phosphate mineralisation, followed by brecciation of quartz-tourmaline rocks as the latest documented stage in the evolution of the rocks. The hematite-limonite matrix of tourmalinites can be interpreted as a fault gauge, though additional field observations are needed to confirm this statement.

In summary, based on textural data (e.g. polygonal fabric, phosphate mineralisation in the cracks), as well as tourmaline, garnet and white mica chemistries, the tourmalinites seem to have undergone Alpine HP metamorphism; therefore the formation of the rock was predating this event. However, the origin of tourmalinites is a matter of debate in the literature and several theories have been proposed (for a review see Slack 1996). Taking into consideration the magmatic-metamorphic evolution of the area the following scenario seems to be a plausible explanation for the formation of tourmalinites in the Sopron area.

During the crystallization of the granitoid intrusion, B-rich fluids could exsolve from the residual melt causing tourmalinization of the country rocks (London et al. 1996). The presence of relict scheelite as inclusions in rutile supports this possibility, as tourmalinites are often closely associated with $\mathrm{Sn}-\mathrm{W}$ greisen deposits, where scheelite can be the main ore mineral (e.g., Slack 1996). Due to the escaping tourmalinizing fluids, rockforming minerals are partially or completely replaced; however, the geochemical signature and relics of the original phase(s) may survive in the newly formed crystals (Henry and Dutrow 1996). In the studied case, these primary tourmaline crystals have Fe-rich overgrowths and Mg-rich crack-fillings, most likely formed during the prograde and retrograde Alpine HP metamorphism, respectively. 


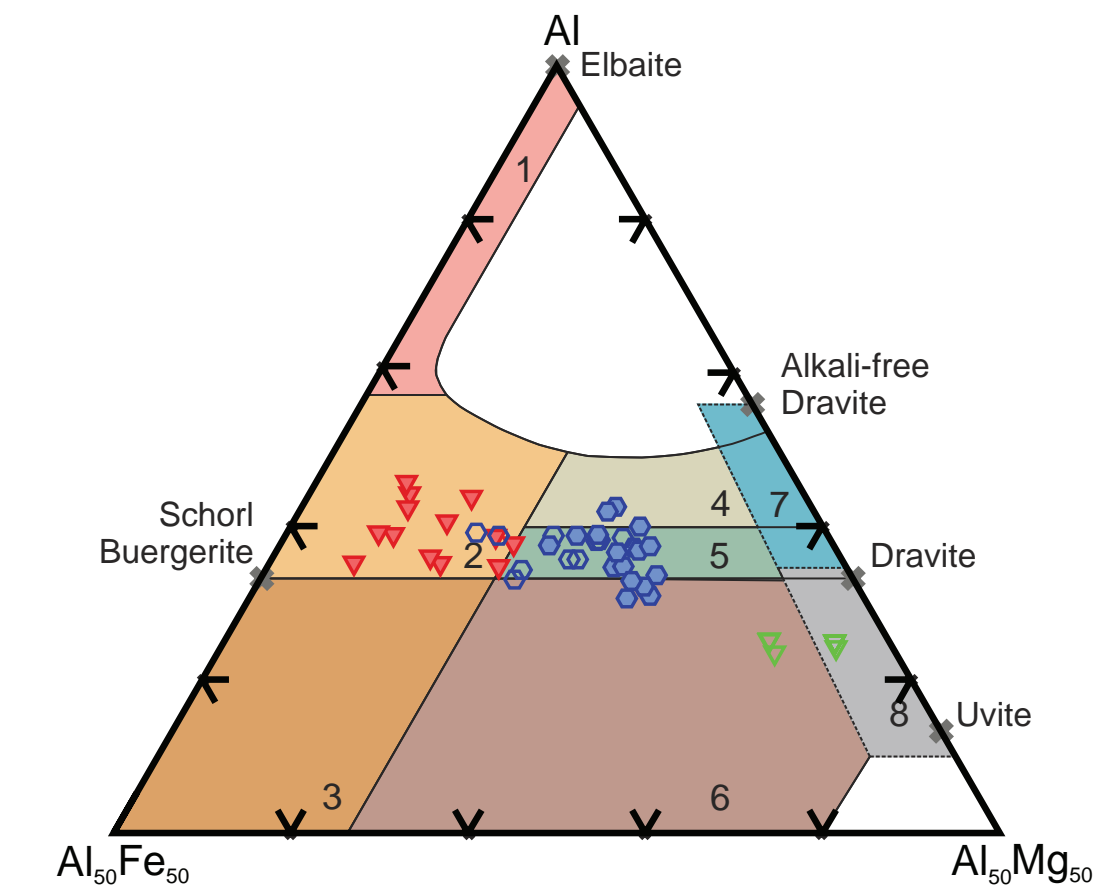

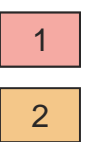

Li-rich granitoid pegmatites and aplites

Li-rich granitoids and their associated pegmatites and aplites

$3 \mathrm{Fe}^{3+}$-rich quartz-tourmaline rocks

4 Metapelites and metapsammites coexisting with an Al-saturated phase
5 Metapelites and metapsammites not coexisting with an Al-saturated phase

$6 \mathrm{Fe}^{3+}$-rich quart-tourmaline rocks, calc-silicate rocks and metapelites

7 Low-Ca metaultramafics and $\mathrm{Cr}$, V-rich metasediments

8 Metacarbonates and meta-pyroxenites
Fig. 11 Distribution of tourmaline compositions from the tourmalinites in the $\mathrm{Al}_{50} \mathrm{Fe}_{50}-\mathrm{Al}-\mathrm{Al}_{50} \mathrm{Mg}_{50}$ triangle. Compositional areas are based on Henry and Guidotti (1985).

\subsection{Kyanite-muscovite-chlorite schists and quartzites}

Based on the studied characteristic assemblage (kyanite, leuchtenbergite and Mg-rich white mica) and the high degree of deformation, the formation of kyanite-muscovite-chlorite schists and quartzites should have been analogous to the development of leucophyllites along shear zones (Mg-metasomatism after Alpine HP peak conditions, Török 2001). Colorless rim of tourmaline, extremely enriched in $\mathrm{Mg}$ (very close to the dravite end member, Fig. 5, Tab. 4) seems to be a further and distinctive marker of the Mg-metasomatic event. Similar tourmaline compositions (\#Mg = 0.99) discussed by Henry and Dutrow (1996) were found as inclusions in

\section{Tourmalinites \\ core, lighter zones \\ inner, darker zones \\ dark brown rim and crack filling \\ light blue-colourless crack filling}

garnets in UHP Mg-rich metapelites from the Western Alps.

The above-mentioned assemblage containing Al-rich phases (kyanite, leuchtenbergite and Mg-rich white mica) implies that the protolith of the studied rocks might have been a micaschist (metapelite) that underwent a strong Mg-metasomatism. Tourmaline grains in the sheared veins and bands in kyanite-bearing quartzites and schists may have originated from a micaschist. On the other hand, the Mg-rich overgrowths often with a replacing boundary (clear dravite rims) might have formed during the formation of leucophyllites. The sillimanite inclusions in muscovites may preserve the Permo-Triassic HT metamorphic imprint, similarly to the micaschists of the Kovács-árok described by Török (1999). 


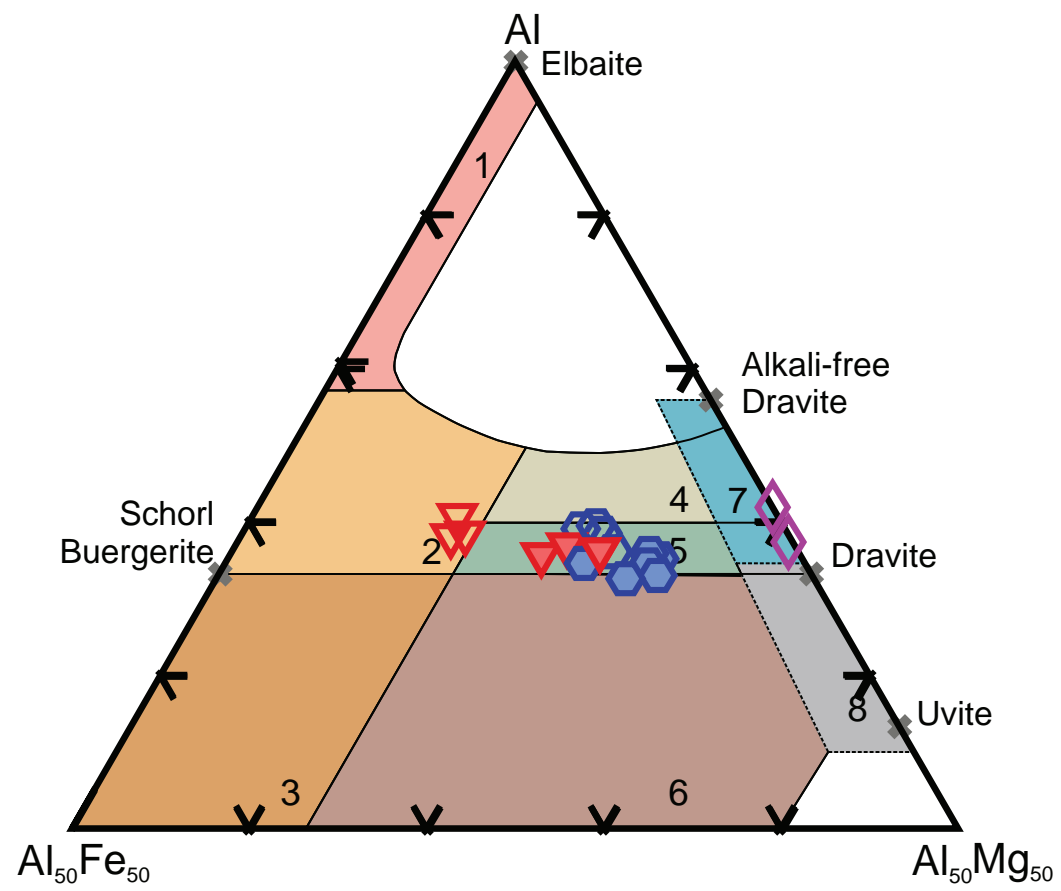

1 Li-rich granitoid pegmatites and aplites

2 Li-rich granitoids and their associated pegmatites and aplites

$3 \mathrm{Fe}^{3+}$-rich quartz-tourmaline rocks

Metapelites and metapsammites coexisting with an Al-saturated phase
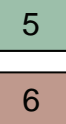

7
Metapelites and metapsammites not coexisting with an Al-saturated phase $\mathrm{Fe}^{3+}$-rich quartz-tourmaline rocks, calc-silicate rocks and metapelites

Low-Ca metaultramafics and $\mathrm{Cr}$, V-rich metasediments

8 Metacarbonates and meta-pyroxenites

\begin{tabular}{|l|}
\hline Kyanite-muscovite-chlorite schist \\
$\square$ core \\
Kyanite-muscovite-chlorite quartzite \\
$\nabla$ core and lighter zones \\
$\nabla$ outer and darker zones \\
$\triangle$ colourless overgrowth
\end{tabular}

Fig. 12 Distribution of tourmaline compositions from the tourmaline-rich kyanite-muscovite-chlorite schists and quartzites in the $\mathrm{Al}_{50} \mathrm{Fe}_{50}-\mathrm{Al}-\mathrm{Al}_{50} \mathrm{Mg}_{50}$ triangle. Compositional areas are based on Henry and Guidotti (1985).

\subsection{Summary on tourmalines}

We assume that tourmaline-rich orthogneisses are the products of late-magmatic fluid rich crystallization of the granitoid intrusion. As these rocks are not abundant in the area at all, described only in two small outcrops (see Tab. 1), the enrichment in fluid components could be a local phenomenon during the crystallization of the pluton. Although magmatic tourmaline cores in orthogneisses do not show a large compositional variability (Fig. 10), they fall to a coherent compositional field probably reflecting the crystallization of the igneous body interacting with the host rock. Optically, a lighter inner core can be distinguished with a sharp boundary, but this difference (Fig. $3 b$ ) is not accompanied with any change in major- element composition (possibly just minor change in $\mathrm{Fe}^{3+} / \mathrm{Fe}_{\text {tot }}$ ratio but this was not determined here). There is no textural evidence for detrital origin of the tourmaline cores, as they are completely euhedral without any sign of rounding or dissolution. Therefore, this zoning could be interpreted as a change in growth conditions. Dark brown rims and crack-fillings of tourmaline are generally enriched in Fe; however, they show a bigger variation in the $\mathrm{Fe}-\mathrm{Al}-\mathrm{Mg}$ triangle (Fig. 10). This variability (especially the depletion in $\mathrm{Al}$ ) can be explained by metamorphic dissolution and reprecipitation of the 

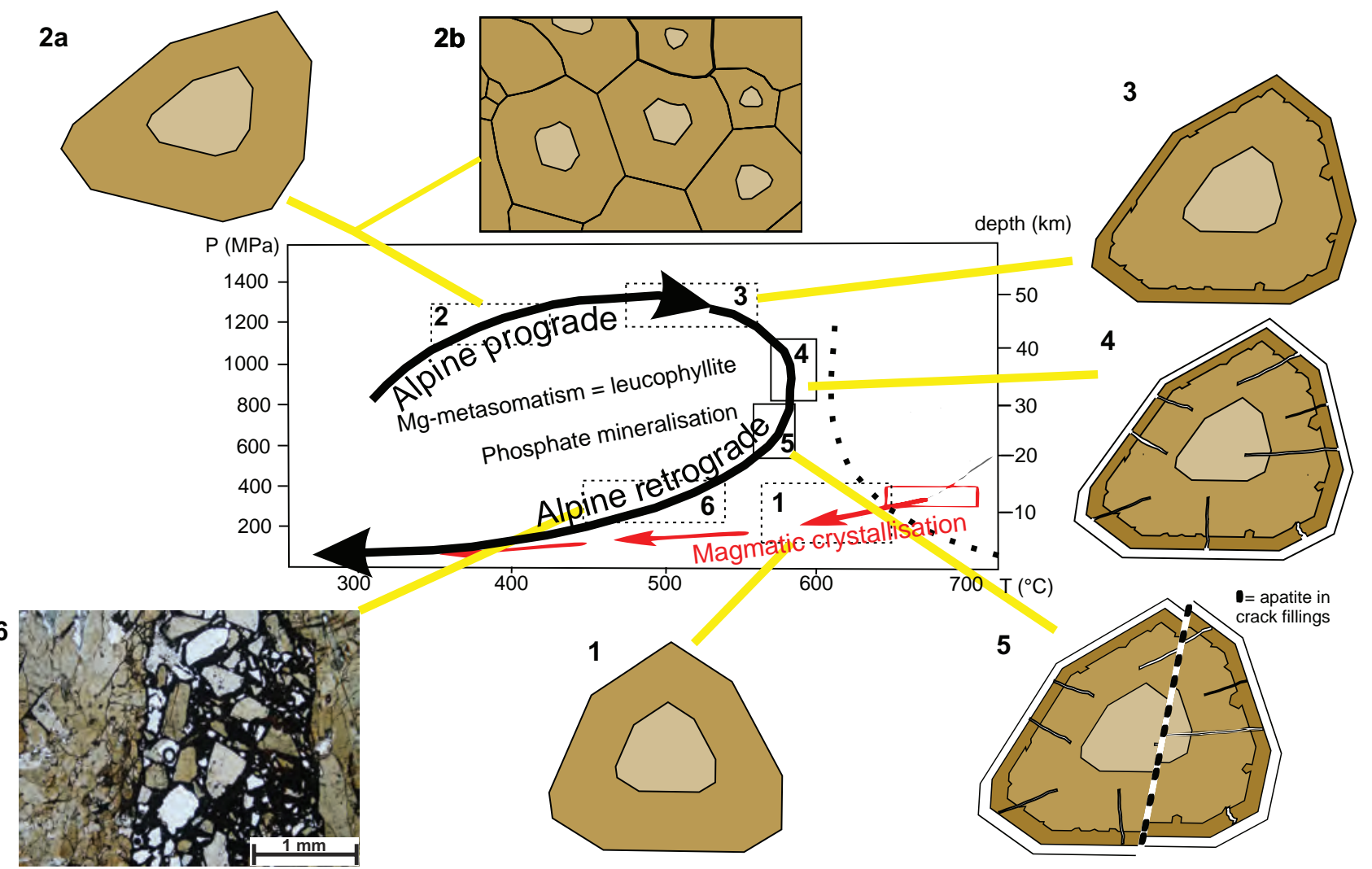

Fig. 13 Tenative magmatic and metamorphic evolution of tourmalines in orthogneisses and tourmalinites of the Sopron area. P-T paths after Török (2001). (1) Tourmaline crystallization in granites and pegmatites, the composition $(\mathrm{Mg} / \mathrm{Fe})$ can be influenced by the interaction with the host rock (micaschist); tourmalinites form when B-rich fluids are released from the granitoid. (2) Deformed (2a) and polygonal fabric (2b) develops during Alpine prograde metamorphism, the latter in tourmalinites. (3) Near the Alpine peak metamorphism, Fe-rich schorl is formed (as dark brown rims and crack fillings). (4) Parallel to the formation of leucophyllites (Mg-metasomatism), Mg-rich dravite grows. (5) Phosphate mineralisation, caused by retrograde high-salinity fluids, appears in the cracks of tourmaline grains. (6) Brecciation of quartz-tourmaline rocks.

tourmaline in cracks that were opened by deformation. This tourmaline is almost always associated with white mica (Fig. 3b) competing for Al, resulting in Al-poor tourmaline compositions.

In course of the pluton crystallization, B-rich fluids interacted with the host-rock and presumably caused the formation of tourmalinite. This nevertheless is a very rare lithology in the Sopron area (observed in one locality, Tab. 1) and thus may indicate only a local process. Due to the poor outcrop situation, trenches should be made to study the extent and contact zones of tourmalinites and the boundary of tourmaline-bearing rocks. Tourmaline cores in tourmalinites often have an inner lighter core (Fig. 4b), similarly to orthogneisses described above, but the boundary is optically rather gradual. This is not accompanied with significant major-element change, either. So the growth zoning is more likely than a detrital origin. However, specifying the role and significance of zone boundaries and development requires further research.

Formation of leucophyllites during Mg-metasomatism proves to be a regionally important process in the Eastern Alps (Török 2001). It caused significant changes in bulkrock compositions of different lithologies (orthogneisses and micaschists alike, Török 2001) during retrograde metamorphism, but only in discrete areas (along shear zones). Therefore Mg-rich tourmaline generation (near end-member dravite) in association with Mg-rich chlorite and Mg-rich muscovite could be an important additional indicator of the Mg-metasomatism in the Sopron area.

\section{Conclusions}

In summary, the analysed, newly described tourmalinerich rocks of the Sopron area can be correlated very well with previously described metamorphic rocks and events from the region based on textural and majorelement chemical signatures. The presence of tourmaline in large quantities provides fresh insight into the magmatic, metamorphic and metasomatic evolution of the area. From the perspective of tourmaline in orthogneisses and tourmalinites, a probable magmatic and metamorphic evolution can be proposed (Fig. 13). With petrography and major-element mineral chemistry, only the sequence of tourmaline generations can be determined precisely. Calibrating the $\mathrm{P}-\mathrm{T}-\mathrm{t}$ path needs 
further thermobarometric, fluid-inclusion, trace-element and isotopic studies.

Considering the geological evolution of the Sopron area, the published data, complemented with results of our research, indicate the following series of events:

1) Deposition of alternating layers of pelitic and psammitic sediments - the Early Paleozoic protolith of micaschists

2) Variscan regional metamorphism (first metamorphic tourmaline generation in micaschist?)

3) Variscan intrusion of a peraluminous leucogranite into the micaschist:

- crystallization of granitic melt (perthitic K-feldspar, antiperthitic plagioclase, Fe-Mn-garnet, white mica with low Si and high Ti)

- subsolidus formation of pegmatites in fluid-rich environment (beryl, tourmaline and low-Ti white mica)

- crystallization of magmatic-pegmatitic tourmaline, composition and quantity of which was influenced by the interaction with the host rock (loss of B-rich fluids)

- contact-metasomatic tourmalinization of the country rock by volatile-rich fluids released from the granitoid (tourmalinite with mica relics and scheelite)

4) Permo-Triassic HT metamorphism (sillimanite relics in muscovites of tourmaline-rich kyanite-muscovitechlorite schist)

5) Alpine HP metamorphism:

- Variscan leucogranite turns into orthogneiss (foliation, dynamic recrystallization structures in quartz, phengite, Ca-rich garnet rims, Fe-rich tourmaline generation?)

- prograde metamorphism of tourmalinite (deformation, polygonal morphology due to static recrystallization, phengite, Ca-rich garnet, kyanite, Fe-rich tourmaline generation?)

- metamorphism of micaschists (Ca-rich garnet, second metamorphic tourmaline generation in micaschist?)

6) Mg-metasomatism after the Alpine metamorphic peak along shear zones (formation of leucophyllites - Mgrich mineral assemblage):

- alteration of orthogneisses (kyanite, leuchtenbergite, high-Mg white mica, Mg-rich tourmaline generation)

- alteration of tourmalinites (Mg-rich tourmaline generation, Mg-rich chlorite)

- formation of kyanite-muscovite-chlorite schist and quartzite (Mg-rich white mica, Mg-rich tourmaline-rim generation).

7) REE-rich phosphate mineralisation during Alpine retrograde metamorphism:

- alteration of orthogneisses (lazulite, florencite, goyazite, crandallite, plumbogummite, apatite, monazite and xenotime)

- alteration of tourmalinites (apatite and monazite in veins)
- apatite in kyanite-muscovite-chlorite schist and quartzite?

8) Late-stage retrograde alterations:

- formation of quartz-tourmaline breccias with limonitic-hematitic matrix

The multi-stage development of the magmatic-metamorphic complex in the Sopron area is a good example of complexity of geological processes and preservation of their evidence in geological record.

Acknowledgements. We are very grateful to Gábor Mesics and Mónika Nagy who helped us during the fieldwork and sampling. The research was supported by the New National Excellence Program of the Ministry of $\mathrm{Hu}-$ man Capacities, Hungary ELTE/105/2016. The authors received numerous valuable and helpful comments from Igor Broska, Vincent van Hinsberg, Milan Novák and Jan Cempírek improving both the style and the content of the manuscript.

\section{References}

Balen D, Petrinec Z (2011) Contrasting tourmaline types from peraluminous granites: a case study from Moslavačka Gora (Croatia). Mineral Petrol 102: 117-134

BALOGH K, DunKL I (2005) Argon and fission track dating of Alpine metamorphism and basement exhumation in the Sopron Mts (Eastern Alps, Hungary): thermochronology or mineral growth? Mineral Petrol 83: 191-218

Cave BJ, Stepanov AS, Craw D, Large RR, Halpin JA, Thompson J (2015) Release of trace elements through the sub-greenschist facies breakdown of detrital rutile to metamorphic titanite in the Otago Schist, New Zealand. Canad Mineral 53: 379-400

Demény A, Sharp ZD, Pfeifer HR (1997) Mg-metasomatism and formation conditions of Mg-chlorite-muscovitequartzphyllites (leucophyllites) of the Eastern Alps (W. Hungary) and their relations to Alpine whiteschists. Contrib Mineral Petrol 128: 247-260

Ertl A, Mali H, Schuster R, Körner W, Hughes JM, BRANDSTÄTter F, TILlmanns E (2010) Li-bearing, disordered Mg-rich tourmaline from a pegmatite-marble contact in the Austroalpine basement units (Styria, Austria). Mineral Petrol 99: 89-104

FreILER Á (2016) ${ }^{226}$ Ra Activity Distribution of Rocks in the Sopron Mts. (West-Hungary). Unpublished PhD. thesis, Eötvös Loránd University, Budapest, pp 1-164

FÜLÖP J (1990) Geology of Hungary. Paleozoic I. Geological Institute of Hungary, Budapest, pp 1-325 (in Hungarian)

HenRY DJ, BRODTKoRb MK (2009) Mineral chemistry and chemical zoning in tourmalines, Pampa del Tamboreo, San Luis, Argentina. J South Am Earth Sci 28: 132-141 
Henry DJ, Dutrow BL (1996) Metamorphic tourmaline and its petrologic applications. In: Grew ES, ANOvitz LM (eds) Boron: Mineralogy, Petrology and Geochemistry. Mineralogical Society of America Reviews in Mineralogy 33: 503-557

Henry DJ, Guidotti C (1985) Tourmaline as a petrogenetic indicator mineral: an example from the staurolite-grade metapelites of NW Maine. Amer Miner 70: 1-15

JanÁK M, PlašIENKa D, Cosca M, Schmidt ST, LuptáK B, TörÖK K, Koroknai B, Horváth P, BAlOGH K, DunkL I (2001) Eoalpine metamorphism in the Sopron Mountains, Eastern Alps (Hungary) and the Veporic Unit, Central Western Carpathians (Slovakia, Hungary): evidence for Cretaceous crustal collision in the eastern continuation of the Austroalpine units. J Conf Abstr 6: 566

Kisházi P, Ivancsics J (1987a) Petrogenesis of the Sopron Micaschist Formation. Bull Hung Geol Soc 117: 203-221 (in Hungarian with English abstract)

KisházI P, Ivancsics J (1987b) Contribution to the problematics of the origin of the leuchtenbergite-bearing metamorphics in the Sopron area. Bull Hung Geol Soc 117: 31-45 (in Hungarian with English abstract)

LelKes-Felvári GY, SASSI FP (1983) Sketch of formation of pre-Alpine metamorphic rocks in Hungary. Annual report of the Hungarian Geological Society in 1981: 449-466 (in Hungarian)

Lelkes-Felvári Gy, SASsi FP, Visoná D (1984) Pre-Alpine and Alpine developments of the Austridic basement in the Sopron area (Eastern Alps, Hungary). Rc Soc Ital Mineral Petrologia 39: 593-612

London D, Morgan GB, Wolf MB (1996) Boron in granitic rocks and their contact aureoles. In: GREw ES, Anovitz LM (eds) Boron: Mineralogy, Petrology and Geochemistry. Mineralogical Society of America Reviews in Mineralogy 33: 299-330

Marks MA, Marschall HR, Schühle P, Guth A, Wenzel T, JACOB DE, MARKL G (2013) Trace element systematics of tourmaline in pegmatitic and hydrothermal systems from the Variscan Schwarzwald (Germany): the importance of major element composition, sector zoning, and fluid or melt composition. Chem Geol 344: 73-90

Plašienka D, JANÁK M, Lupták B, Milovský R, Frey M (1999) Kinematics and metamorphism of a Cretaceous core complex: the Veporic unit of the Western Carpathians. Phys Chem Earth A 24: 651-658

PLIMER IR (1987) The association of tourmalinite with stratiform scheelite deposits. Miner Depos 22: 282-291

RAITH JG (1988) Tourmaline rocks associated with stratabound scheelite mineralization in the Austroalpine Crystalline Complex, Austria. Mineral Petrol 39: 265-288

SLACK JF (1982) Tourmaline in Appalachian-Caledonian massive sulphide deposits and its exploration significance. Trans Inst Min Metall, B 91: B81-B89

SLACK JF (1996) Tourmaline associations with hydrothermal ore deposits. In: Grew ES, ANOvitz LM (eds) Boron: Mineralogy, Petrology and Geochemistry. Mineralogical Society of America Reviews in Mineralogy 33: 559-643

TöRÖK K (1996) High-pressure/low temperature metamorphism of the Köhegy Gneiss, Sopron (W-Hungary); phengite barometry and fluid inclusions. Eur J Mineral 8: 917-925

TöRöK K (1998) Magmatic and high-pressure metamorphic development of orthogneisses in the Sopron area, Eastern Alps (W-Hungary). Neu Jb Mineral, Abh 173: 63-91

TöRöK K (1999) Pre-alpine development of the andalusitesillimanite-biotite-schist from the Sopron Mountains (Eastern Alps, Western Hungary). Acta Geol Hung 42: 127-160

TöRÖK K (2001) Multiple fluid migration events in the Sopron gneisses during the Alpine high-pressure metamorphism as recorded by bulk-rock and mineral chemistry and fluid inclusions. Neu Jb Mineral, Abh 177: 1-36

TöRÖK K (2003) Alpine P-T path of micaschists and related orthogneiss veins near Óbrennberg (W-Hungary, Eastern Alps). Neu Jb Mineral, Abh 179: 101-142

Uher P, Mikuš T, Milovský R, Biroň A, SPIŠIAK J, LiPKA J, JAHN J (2009) Lazulite and Ba, Sr, Ca, K-rich phosphates-sulphates in quartz veins from metaquartzites of Tríbeč Mountains, Western Carpathians, Slovakia: compositional variations and evolution. Lithos 112: 447-460

Whitney DL, Evans BW (2010) Abbreviations for names of rock-forming minerals. Amer Miner 95: 185-187

ZAHID M, ArIF M, Moon CJ (2013) Petrogenetic implications of the mineral-chemical characteristics of scheelite and associated phases from Miniki Gol (Chitral), NW Pakistan. Geosci J 17: 403-416 